\title{
Knowledge and attitudes of nursing professors and students concerning the interface between spirituality, religiosity and health
}

\author{
Claudia de Souza Tomasso ${ }^{1}$ \\ Ideraldo Luiz Beltrame ${ }^{2}$ \\ Giancarlo Lucchetti ${ }^{3}$
}

\begin{abstract}
This study compares the knowledge and attitudes of nursing professors and students concerning the interface between spirituality, religiosity and health. A cross-sectional study was conducted with 30 nursing professors and 118 students. The results reveal that more than $95 \%$ of the participants had some religious affiliation, $96 \%$ believed that spirituality considerably influences patients' health, and 77\% wished to address this subject. However, only $36 \%$ felt prepared for it and most believed that the university did not provide the necessary information. No statistical differences were found between the religious practices of nursing professors and students, though a marked difference was found in their clinical practices and opinions concerning spirituality and its inclusion in the program's curriculum. The most common barriers to addressing such a subject were: fear of imposing one's own beliefs, lack of time, and fear of offending patients.
\end{abstract}

Descriptors: Spirituality; Nursing; Teaching.

${ }^{1}$ RN. E-mail: clautomasso@uninove.edu.br.

2 Social Scientist, Ph.D. in Public Health, Full Professor, Diretoria de Ciências da Saúde, Universidade Nove de Julho, São Paulo, SP, Brazil. E-mail: idbeltrame@uninove.br.

${ }^{3}$ Physician, Doctoral Student in Neurology, Universidade Federal de São Paulo, SP, Brazil. Coordinator, Departamento de Pesquisa, Associação Médico-Espírita de São Paulo, SP, Brazil. E-mail: g.lucchetti@yahoo.com.br.

Corresponding Author:

Giancarlo Lucchetti

Av. Juriti, 367, Apto. 131

Bairro: Moema

CEP: 04520-000, São Paulo, SP, Brasil

E-mail: g.lucchetti@yahoo.com.br 


\section{Conhecimentos e atitudes de docentes e alunos em enfermagem na interface espiritualidade, religiosidade e saúde}

Objetivou-se com o presente estudo comparar conhecimentos e atitudes dos docentes e discentes de Enfermagem frente à interface espiritualidade, religiosidade e saúde. Para isso, realizou-se estudo transversal, com 30 docentes e 118 discentes de Enfermagem. Como resultados, mais de $95 \%$ dos participantes possuíam algum tipo de filiação religiosa, $96 \%$ acreditavam que a espiritualidade influenciava muito na saúde do paciente, e $77 \%$ sentiam vontade de abordar o assunto. Entretanto, somente $36 \%$ julgavam-se preparados, e a maioria acreditava que a universidade não proporcionava todas as informações necessárias sobre o tema. Não houve diferenças estatísticas entre a religiosidade de docentes e discentes de Enfermagem, porém, houve marcante diferença entre suas práticas clínicas e opiniões a respeito da espiritualidade e de sua implementação no currículo. As principais barreiras ao abordar o assunto foram: medo de impor as próprias crenças, falta de tempo e medo de ofender os pacientes.

Descritores: Espiritualidade; Enfermagem; Ensino.

\section{Comparación de conocimientos y actitudes de los profesores y estudiantes de enfermería frente a las relaciones entre espiritualidad, religión y salud}

El presente estudio tuvo como objetivo comparar conocimientos y actitudes de los profesores y estudiantes de enfermería frente al enlace entre Espiritualidad, Religiosidad y Salud. Se trata de un estudio transversal, con 30 profesores y 118 estudiantes de enfermería. Como resultados se obtuvo que más de $95 \%$ de los participantes poseían algún tipo de afiliación religiosa, 96\% creían que la espiritualidad influenciaba mucho en la salud del paciente y $77 \%$ sentían deseos de abordar el asunto. Entretanto, solamente $36 \%$ se juzgaban preparados y la mayoría creía que la universidad no proporcionaba todas las informaciones necesarias sobre el tema. No hubo diferencias estadísticas entre la religiosidad de profesores y estudiantes de enfermería, sin embargo hubo una clara diferencia entre sus prácticas clínicas y opiniones al respecto de la espiritualidad y de su implementación en el currículo. Las principales barreras para abordar el asunto fueron: miedo de imponer las propias creencias, falta de tiempo y miedo de ofender a los pacientes.

Descriptores: Espiritualidad; Enfermería; Enseñanza.

\section{Introduction}

Nursing has emphasized the importance of acknowledging religion and spirituality as sources of strength to cope with disease ${ }^{(1)}$. Religion has occupied a privileged place in Brazilian nursing history. Sometimes, one becomes the spokesperson of the other in the elaboration of thought and consolidation of attitudes that influence the education and practice of nurses and nursing auxiliaries(2).

Religiosity and spirituality have been shown to have a potential impact on physical health, be a potential protection factor in preventing diseases progressing in a previously healthy population, to lead to potential increased survival, and to have an impact on diverse diseases $^{(3)}$.

Recent studies show that people with greater religiosity or spirituality have a greater general wellbeing, lower prevalence of depression, lower consumption of illegal or legal drugs, lower incidence of suicide, better quality of life, greater survival, and shorter duration of hospitalization, among other associations ${ }^{(4)}$. 
Spirituality and its relation with health has become a paradigm to be established in daily clinical practice ${ }^{(5)}$. Practice says that "nurses are not only responsible for the patient's material dimension when delivering care; the patient is a live being who suffers in his/her whole: body, mind and spirit". Nurses are trained to help patients acknowledge their condition, face personal conflicts, and alleviate their suffering(6).

The education of nursing students is probably one of the most important times for their future career. The contact with professors and clinical experience end up molding their attitudes in relation to colleagues and patients. The manner in which spirituality is taught by professors and perceived by students can lead to a greater understanding of this dimension in care delivery.

This study compares knowledge and attitudes of nursing professors and students in the face of the interface of spirituality, religiosity and health.

\section{Method}

Study's design: Cross-sectional with a quantitative approach.

Place and time of data collection: The study was carried out in the campuses of the Nursing Faculty, Nove de Julho University (UNINOVE) in São Paulo, Brazil from September to November 2010.

Population and sample: the study included an evaluation of two groups: professors and students enrolled in the nursing program. The participants were selected according the following:

Professors: were randomly and consecutively selected (according to their presence in the Memorial campus); the participation of 30 professors from the nursing program was expected (Nurses affiliated to the UNINOVE at the Memorial campus) through a verbalized invitation. These were personally contacted and asked to fill out a standard questionnaire.

Students: Due to the large number of nursing students, we opted to select a convenience sample selecting four different classes of 30 students each, totaling 120 students (one class from the second semester, one from the fourth semester, one from the sixth semester, and one from the eighth semester). The students were also invited and personally approached before classes and breaks. The choice of different classes attending different semesters aimed to compare these students' behavior and knowledge in relation to the topic during nursing education.
Inclusion and exclusion criteria: All the professors and students who voluntarily consented to participate in the study and who signed free and informed consent terms were included in the study. Those who were not located or did not want to participate were excluded.

Data collection instrument: All the participants filled in a self-applied standard instrument (28 questions). This questionnaire was adapted from an ongoing multicenter study involving medical students coordinated by the Federal University of São Paulo. It consists of: Socio-demographic data: gender, age, family income, ethnicity and what semester in the program.

Religiosity and spirituality of the participants: evaluation of multiple dimensions of religiosity through religious affiliation and the Duke Religion Index validated in Brazil( $^{(7)}$. This scale is composed of five questions and evaluates three types of religiosity: organizational (religious frequency of attendance), non-organizational (praying, Bible reading, meditation, among others) and intrinsic religiosity.

Clinical Practice, the patient and spirituality: knowledge and opinions concerning the relationship between spirituality and health, including the context of the clinical practice of nurses.

Academic education and the subject 'spirituality': how the university addresses the theme and how it should address the theme.

Concept of spirituality: the concept of spirituality indicated by the participants.

Statistical analysis: Data were compiled in Excel and analyzed through the SPSS 17.0. Contingent tables and summary measures were first developed concerning the opinions and attitudes of the participants. Chisquare analysis was performed for the categorical variables to compare the differences of opinions and attitudes of professors and students in relation to the topic. Confidence interval was $95 \%$ and $p<0.05$.

Ethical aspects: All the participants read and signed free and informed consent forms. The study was approved by the Ethics Research Committee at Nove de Julho University.

\section{Results}

The final sample was composed of 30 professors of the nursing program and 118 nursing students (29 from the second semester, 29 from the fourth semester, 30 from the sixth semester and 30 from the eighth semester). The rate of answers to the questionnaire was $100 \%$ among professors and $98.3 \%$ among students. 
Only two students did not answer the questionnaire; both reported a lack of time to participate in the study.

\section{Characteristic and comparison of the participant's socio-demographic variables}

The professors were mostly female, older than 35 years of age, Caucasian and with salaries greater than seven times the minimum wage. The students were also mostly female, younger than 35 years of age, Caucasian (with the exception of the sixth semester) and had an income below seven times the minimum wage. No statistical differences were found in the comparison between professors and students and among students in relation to gender. A clear difference was observed between the average age of professors and that of students; the first group was older $(p<0.001)$.

A statistical difference in relation to the variable 'income' was observed between professors (greater income) and students (lower income) $(p<0.001)$ but not among students. In terms of ethnicity, only the sixth semester was predominantly composed of ethnic groups other than Caucasian

\section{Characteristics and comparison of the religious variables for the participants}

The great majority of participants had some religious affiliation and the following results were obtained in relation to organizational, non-organizational and intrinsic religiosity: most attended a church service at least once a week, about $50 \%$ practiced a private religiosity (praying, religious reading, TV programs, meditation), and most obtained high scores on the intrinsic religious scale. No statistical difference was observed in the comparison of religiosity and religious affiliation between the groups; the sample is homogeneous in this aspect.

\section{The nurses' clinical practice concerning spirituality}

In relation to the clinical practice of nurses, most believed that spirituality influences the health of patients (more than $90 \%$ in some cases), about half believed that spirituality influences a nurse's care delivery and most reported they felt confortable in addressing the topic but did not feel prepared for that (Tables 1 and 2).

When professors and students were compared, professors felt more prepared to address the theme than students (a statistically significant difference). Similarly, more advanced students also felt more prepared than those from the second semester. Another important piece of information was that the eighth semester reported being less willing to approach the theme compared to professors. This difference does not appear when they are compared to the other students.

Table 1 - Nurses' clinical practice concerning spirituality

\begin{tabular}{|c|c|c|c|c|c|c|c|c|}
\hline & \multicolumn{2}{|c|}{$\begin{array}{c}\text { Does spirituality influence the } \\
\text { health of patients? }\end{array}$} & \multirow{2}{*}{$\mathbf{p}^{*}$} & \multirow{2}{*}{$\mathbf{p}^{\dagger}$} & \multicolumn{2}{|c|}{$\begin{array}{l}\text { Does the nurse's spirituality } \\
\text { affect in care delivery? }\end{array}$} & \multirow{2}{*}{$\mathbf{p}^{*}$} & \multirow{2}{*}{$\mathbf{p}^{\dagger}$} \\
\hline & A lot & A little & & & A lot & A little & & \\
\hline Professors & $86,7 \%$ & $13,3 \%$ & & & $43,3 \%$ & $56,7 \%$ & & \\
\hline $2^{\text {nd }}$ semester & $89,7 \%$ & $17,6 \%$ & 0,723 & & $37,9 \%$ & $62,1 \%$ & 0,673 & \\
\hline $4^{\text {th }}$ semester & $79,3 \%$ & $20,7 \%$ & 0,455 & 0,285 & $37,9 \%$ & $62,1 \%$ & 0,605 & 1,000 \\
\hline $6^{\text {th }}$ semester & $90,0 \%$ & $10,0 \%$ & 0,688 & 0,965 & $50,0 \%$ & $50,0 \%$ & 0,605 & 0,352 \\
\hline $8^{\text {th }}$ semester & $96,6 \%$ & $3,4 \%$ & 0,204 & 0,323 & $50,0 \%$ & $50,0 \%$ & 0,467 & 0,352 \\
\hline
\end{tabular}

*Chi-square, reference "professor"

${ }^{+}$Chi-square, reference " 2 nd semester"

Table 2 -Nurses' clinical practice concerning spirituality

\begin{tabular}{|c|c|c|c|c|c|c|c|}
\hline \multicolumn{2}{|c|}{ Do you want to address it? } & \multirow{2}{*}{$\mathbf{p}^{*}$} & \multirow{2}{*}{$\mathbf{p}^{\dagger}$} & \multicolumn{2}{|c|}{ Do you feel prepared? } & \multirow{2}{*}{$\mathbf{p}^{*}$} & \multirow{2}{*}{$\mathbf{p}^{\dagger}$} \\
\hline Yes & No & & & A lot & A little & & \\
\hline $90,0 \%$ & $10,0 \%$ & & & $66,7 \%$ & $33,3 \%$ & & \\
\hline $75,9 \%$ & $24,1 \%$ & 0,159 & & $6,9 \%$ & $93,1 \%$ & 0,000 & \\
\hline $79,3 \%$ & $20,7 \%$ & 0,263 & 0,753 & $37,9 \%$ & $62,1 \%$ & 0,029 & 0,011 \\
\hline $73,3 \%$ & $26,7 \%$ & 0,107 & 0,824 & $26,7 \%$ & $73,3 \%$ & 0,003 & 0,059 \\
\hline $66,7 \%$ & $33,3 \%$ & 0,037 & 0,437 & $43,3 \%$ & $56,7 \%$ & 0,072 & 0,004 \\
\hline
\end{tabular}

*Chi-square, reference "professor"

${ }^{+}$Chi-square, reference " $2^{\text {nd }}$ semester" 


\section{The approach of nurses concerning spirituality}

In evaluating 'nurses' clinical practice concerning spirituality', professors believe that addressing the subject is more appropriate than do students in the second and sixth semesters. Among the students, those in their fourth semester believed that such an approach was more appropriate than those in the second semester, but such a difference was not observed in relation to the sixth and eighth semesters (Table 3 ).

When they were asked whether they had ever addressed this topic and with what frequency, more professors answered affirmatively in comparison to students; a statistically significant difference was found in relation to the second, fourth and sixth semesters. However, in general, few participants reported asking about their patients' spirituality.

Table 3 - The approach of nurses concerning spirituality

\begin{tabular}{|c|c|c|c|c|c|c|c|c|c|c|c|c|}
\hline & \multicolumn{2}{|c|}{$\begin{array}{l}\text { Is it appropriate to } \\
\text { approach it? }\end{array}$} & \multirow[t]{2}{*}{$\mathbf{p}^{*}$} & \multirow[t]{2}{*}{$\mathbf{p}^{\dagger}$} & \multicolumn{2}{|c|}{$\begin{array}{l}\text { Did you ever ask } \\
\text { about it? }\end{array}$} & \multirow{2}{*}{$\mathbf{p}^{*}$} & \multirow{2}{*}{$\mathbf{p}^{\dagger}$} & \multicolumn{2}{|c|}{$\begin{array}{l}\text { How frequently do } \\
\text { you ask about it? }\end{array}$} & \multirow{2}{*}{$\mathbf{p}^{*}$} & \multirow[t]{2}{*}{$\mathbf{p}^{\dagger}$} \\
\hline & A lot & A little & & & Yes & No & & & Usually & Rarely & & \\
\hline Professors & $89,7 \%$ & $10,3 \%$ & & & $83,3 \%$ & $16,7 \%$ & & & $30,0 \%$ & $70,0 \%$ & & \\
\hline 2nd semester & $51,7 \%$ & $48,3 \%$ & 0,003 & & $42,9 \%$ & $57,1 \%$ & 0,002 & & $3,4 \%$ & $96,6 \%$ & 0,023 & \\
\hline 4th semester & $82,8 \%$ & $17,2 \%$ & 0,451 & 0,015 & $40,7 \%$ & $59,3 \%$ & 0,002 & 0,874 & $10,3 \%$ & $89,7 \%$ & 0,072 & 0,323 \\
\hline 6th semester & $66,7 \%$ & $33,3 \%$ & 0,042 & 0,245 & $61,5 \%$ & $38,5 \%$ & 0,072 & 0,172 & $6,7 \%$ & $93,3 \%$ & 0,032 & 0,580 \\
\hline 8th semester & $73,3 \%$ & $26,7 \%$ & 0,119 & 0,090 & $65,5 \%$ & $34,5 \%$ & 0,123 & 0,089 & $4,7 \%$ & $76,7 \%$ & 0,560 & 0,050 \\
\hline
\end{tabular}

*Chi-square, reference "professor"

${ }^{+}$Chi-square, reference " 2 nd semester"

Opinion of nursing professors and students concerning undergraduate education in spirituality

Only three participants ( $2.0 \%$ of the total) reported that college education provided sufficient information (quite or very much) about the subject; no statistically significant difference was found among groups. Most saw the need to include the subject in the curriculum. The second semester students showed little interest in having such a subject included in the curriculum.
When asked whether the students should be prepared for this subject during undergraduate education, more professors than students answered yes. Most said that the subject had never been addressed during their undergraduate program (45.3\%), and those who did reported the subject as having been addressed reported it occurred between the second and sixth semesters (Tables 4 and 5).

Table 4 - Opinions of nursing professors and students concerning the topic 'spirituality' being addressed during undergraduate education

\begin{tabular}{|c|c|c|c|c|c|c|c|}
\hline \multicolumn{2}{|c|}{$\begin{array}{l}\text { Undergraduate education provides } \\
\text { enough information }\end{array}$} & \multirow[t]{2}{*}{$\mathbf{p}^{*}$} & \multirow[t]{2}{*}{$\mathbf{p}^{\dagger}$} & \multicolumn{2}{|c|}{ It should be part of the curriculum } & \multirow[t]{2}{*}{$\mathbf{p}^{*}$} & \multirow[t]{2}{*}{$\mathbf{p}^{\dagger}$} \\
\hline A lot & A little & & & Yes & No & & \\
\hline $8,0 \%$ & $92,0 \%$ & & & $86,7 \%$ & $13,3 \%$ & & \\
\hline $0,0 \%$ & $100,0 \%$ & 0,998 & & $57,1 \%$ & $42,9 \%$ & 0,016 & \\
\hline $3,6 \%$ & $96,4 \%$ & 0,497 & 0,998 & $82,8 \%$ & $17,2 \%$ & 0,677 & 0,040 \\
\hline $0,0 \%$ & $100,0 \%$ & 0,998 & 1,000 & $85,7 \%$ & $14,3 \%$ & 0,916 & 0,023 \\
\hline $0,0 \%$ & $19,4 \%$ & 0,998 & 1,000 & $73,3 \%$ & $26,7 \%$ & 0,204 & 0,198 \\
\hline
\end{tabular}

*Chi-square, reference "professor"

${ }^{+}$Chi-square, reference " 2 nd semester" 
Table 5 - Opinions of nursing professors and students concerning education in spirituality provided during the undergraduate program

\begin{tabular}{|c|c|c|c|c|c|c|c|}
\hline \multicolumn{2}{|c|}{ Students should be prepared for it } & \multirow{2}{*}{$\mathbf{p}^{*}$} & \multirow{2}{*}{$\mathbf{p}^{\dagger}$} & \multicolumn{2}{|c|}{ Have the professors already addressed it? } & \multirow{2}{*}{$\mathbf{p}^{*}$} & \multirow{2}{*}{$\mathbf{p}^{\dagger}$} \\
\hline Yes & No & & & Yes & No & & \\
\hline $74,1 \%$ & $25,9 \%$ & & & $66,7 \%$ & $33,3 \%$ & & \\
\hline $42,3 \%$ & $57,7 \%$ & 0,022 & & $6,9 \%$ & $93,1 \%$ & 0,000 & \\
\hline $46,2 \%$ & $53,8 \%$ & 0,041 & 0,780 & $37,9 \%$ & $62,1 \%$ & 0,029 & 0,011 \\
\hline $42,9 \%$ & $57,1 \%$ & 0,022 & 0,967 & $26,7 \%$ & $73,3 \%$ & 0,003 & 0,059 \\
\hline $40,7 \%$ & $57,1 \%$ & 0,015 & 0,908 & $43,3 \%$ & $56,7 \%$ & 0,072 & 0,004 \\
\hline
\end{tabular}

*Chi-square, reference "professor"

${ }^{+}$Chi-square, reference " $2^{\text {nd }}$ semester"

\section{Participation in spirituality-related activities and continuing education}

When the participants were asked whether they had already participated in some educational activity concerning "Health and Spirituality": 22 (14.9\%) said yes; $109(73.2 \%)$ said no, though they wished to, 15 $(10.1 \%)$ said no and showed no interest in participating in such activity, and two (1.4\%) were not sure. The participants reported they seek information concerning the theme through: lectures addressing the theme $(12.2 \%)$, books $(30.2 \%)$, asking the help of professors $(5.4 \%)$, on religion itself $(38.3 \%)$, and $23.5 \%$ did not seek information.

\section{Concept of spirituality}

When they were asked about the concept of spirituality (checking more than one alternative was possible): most (46.3\%) indicated the concept "Belief and relationship with God/Religiosity" followed by "Search for meaning and significance for human life" (36.9\%); "belief in the existence of soul and life after death" (25.5\%); "Belief in something that transcends matter" (14.1\%), and "Ethical and humanistic posture" $(14.8 \%)$.

\section{Barriers indicated by nursing professors and students}

The main barriers indicated by participants were: fear of imposing their own beliefs (46.6\%), lack of time $(23.0 \%)$, fear of offending patients $(18.9 \%)$, lack of knowledge $(14.9 \%)$, not feeling comfortable with the subject $(14.2 \%)$, lack of training $(10.1 \%)$, other reasons $(9.5 \%)$, "it is not part of my job" $(4.7 \%)$, fear colleagues do not approve of such activities (3.4\%) and knowledge concerning religion is not relevant $(2.7 \%)$.

\section{Discussion}

This study's sample was mainly composed of women and the nursing students were younger than professors, which is similar to the profile found in previous Brazilian studies $^{(8)}$. In relation to religiosity, the participants in this study were religious at a rate similar to the Brazilian population in general. These findings show that undergraduate students (a high educational level) are religious at a rate similar to those with a low educational level, as shown by a recent national survey(9). They also had high levels of intrinsic religiosity, similar to a study carried out with nursing students in Taiwan(10). The comparison between professors and students revealed homogeneity of knowledge and personal practice of religiosity and spirituality, that is, the degree of nursing education did not exert much influence on their cultural values and religious beliefs.

Most participants reported that spirituality influenced the health of patients and nursing care delivery itself. Diverse studies have shown the influence of spirituality in the prevalence of mental disorders, quality of life, survival, time of hospitalization, among others ${ }^{(4,11)}$. Similarly, spirituality is and has been present in nursing care delivery since the most remote times. Florence Nightingale(12), considered the precursor of scientific nursing, brought the legacy of seeing the human being in an holistic way, that is, as a bio-psychosocio-spiritual being, who transcends the physical dimension. Authors indicate that spirituality is "a human dimension in which exist phenomena, such as spiritual distress, which nurses have to diagnose and treat in an autonomous manner"(13). The study's participants seem to understand the importance of this aspect in the lives of their patients.

In relation to the semester in which the subject was addressed, $60 \%$ of the participants reported that 
they had never seen this subject addressed. It seems that spirituality is still seldom addressed in the curricula of nursing programs, in the same way thanatology is, which, despite its great importance, is seldom included in the nursing curriculum ${ }^{(14)}$. This lack of training ends up imposing barriers against nurses addressing this dimension in care delivery; nurses do not feel prepared to address patients' spirituality. A study conducted in 2010 with 30 nurses in cancer and semi-intensive units asked whether the theme 'spirituality' had ever been addressed in these nurses' undergraduate programs. The authors report that only $33 \%$ of the nurses said yes $^{(15)}$ while $83 \%$ stated this topic was important.

In general, few participants addressed their patients' spirituality, which is consistent with other studies addressing health professionals. Only $11 \%$ of the physicians ask their patients about their spiritual beliefs $^{(16-17)}$, as opposed the more than $70 \%$ of the patients would like their physicians to ask about it ${ }^{(16)}$.

Another important facet is that students from more advanced semesters felt more prepared than the other students and had opinions more akin to those of professors. This result may be associated with the experience of students over the course of the program as well as to a closer contact with patients in practical supervised training and a greater exposure to classes that address this subject. Some authors stress the profound transformations students experience during their undergraduate program ${ }^{(18)}$.

The number of participants who reported that the undergraduate program does not satisfactorily (quite or very much) address the subject was surprising. This result is similar to the findings of other researchers addressing professors from a medical program in Botucatu, SP, Brazil in which more than $90 \%$ of the physicians reported that the university did not provide sufficient information to students on this subject ${ }^{(19)}$.

Studies show that most nurses believe that this subject should be included in nursing curricula. Professors from the nursing school at the University of São Paulo were evaluated in 1994 and 66\% of them said they considered teaching spiritual care during the undergraduate program to be important(20). Comparison of information from both studies suggests that this subject has been increasingly considered important in the context of nursing teaching, since more than $86 \%$ stated it is an important subject.

In relation to barriers, the participants reported that in $46 \%$ of the cases there is fear of imposing their beliefs. This fear is justified due to a lack of training and preparation on how to understand spirituality as something broader and not necessarily associated with religiosity. Additionally, this approach should aim to determine the beliefs of patients and not to impose one's own beliefs. Authors state that "whatever the nurse's religious beliefs, s/he should identify the religions of her/his patients and encourage, see, and support such beliefs in all possible ways. The power of faith is unique, and the comfort and certainty that religion offers is a stimulus to life"(21).

A total of $23 \%$ reported lack of time as an additional barrier. This aspect raises the issue that the essence of nursing care has been overtaken by administrative and bureaucratic issues, distancing this professional from having direct contact with patients ${ }^{(22)}$.

Fear of offending patients was reported by $18.9 \%$ of the participants. If we observe recent studies conducted in medical environments, we clearly note that the patients oftentimes desire this subject to be addressed and most do not feel offended ${ }^{(4,16)}$.

When asked whether they had already participated in learning activities related to the theme, most said no but expressed their desire to participate in such activities. This information is relevant because it shows that the students and professors themselves would like to understand and participate in activities related to the theme.

Surprisingly, more than $38 \%$ reported they sought knowledge in a religion itself to the detriment of scientific papers, books or the professors themselves. These findings partially justify the fear of imposing their own beliefs and the difficulties in discriminating religiosity from spirituality. We note that when asked about the concept of spirituality, most choose "Belief and relationship with God/Religiosity" which in the opinion of many authors is more associated with the concept of religiosity. Spirituality can be understood as a personal quest to understand issues related to the end of life, its meaning, about a relationship that is sacred or transcendental, which may or may not lead to the development of religious practices or the development of religious communities(11). The concepts of spirituality and religiosity should undoubtedly be well presented to nursing students and professors to enable a greater understanding and less distortion of these different dimensions.

It is clear that nursing teaching still lacks approaches significantly directed to the holistic care 
of patients. Even though we indirectly note a greater preparedness of more advanced students compared to those attending their first semesters, there are still difficulties and little preparedness experienced during their education. Likewise, the professors themselves are revealed to have difficulty with this subject, which may lead to a certain difficulty in training these students to provide such care.

This study has some limitations that should be taken into account when interpreting the results. First, it is a cross-sectional study and even though it is possible to suggest differences among the semesters, we did not follow the students to see whether there were changes in their behavior concerning the subject. Additionally, the sample was selected from a single university, which may not provide a portrait of the pattern of other nursing schools.

\section{Conclusion}

This study reveals that even though there are no differences between the religious practices of nursing professors and students, there was a marked difference between their clinical practice and opinions concerning spirituality and its inclusion in a curriculum. Most professors believe their students should be prepared to approach this dimension with patients and, therefore, courses addressing health and spirituality should be included in the curriculum.

The conclusion is that there is a lack of information in the face of the interest of many students and professors and a need to implement tools to enable the preparation of students to approach patients to provide as integrative and humanistic care as possible.

\section{References}

1. Carr T. Facing Existential Realities: Exploring Barriers and Challenges to Spiritual Nursing Care. Qual Health Res. 2010;20:1379-82.

2. Gussi MA, Dytz JLG. Religião e espiritualidade no ensino e assistência de enfermagem. Rev Bras Enferm. 2008;61:337-84.

3. Lucchetti G, Almeida L, Granero A. Spirituality for dialysis patients: should the nephrologist address? J Bras Nefrol. 2010;32:128-32.

4. Lucchetti G, Granero A, Bassi R, Latorraca R, Nacif S. Spirituality in clinical practice: what should the general practitioner know? Rev Soc Bras Clín Méd. 2010;8:154-8.
5. Guimarães H, Avezum A. O impacto da espiritualidade na saúde física. Rev Psiquiatr Clín. 2007;34:88-94.

6. de Sá A, Pereira L. Espiritualidade na enfermagem brasileira: retrospectiva histórica. O Mundo da Saúde. 2007;31:225-37.

7. Lucchetti G, Granero Lucchetti A, Peres M, Leão F, Moreira-Almeida A, Koenig $\mathrm{H}$. Validation of the Duke Religion Index: DUREL (Portuguese Version). J Relig Health. 2010 Nov 24. [Epub ahead of print]

8. Wetterich N, Melo M. Sociodemographic profile of undergraduate nursing students. Rev. Latino-Am. Enfermagem 2007;15:404-10.

9. Moreira-Almeida A, Pinsky I, Zaleski M, Laranjeira R. Envolvimento religioso e fatores sociodemográficos: resultados de um levantamento nacional no Brasil. Rev Psiquiatr Clín 2010;37:12-5.

10. Hsiao $Y$, Chiang $H$, Chien L. An exploration of the status of spiritual health among nursing students in Taiwan. Nurse Educ Today. 2010;30:386-92.

11. Koenig $H$, McCullough M, Larson D. Handbook of religion and health: Oxford University Press; 2001.

12. de Sá AC, Pereira LL. Espiritualidade na enfermagem brasileira: retrospectiva histórica. O Mundo da saúde 2007;31:225-37.

13. Cruz ICF. As religiöes afro-brasileiras: subsídios para o estudo da angústia espiritual; Afro-brazilian religions: issues related to the nursing diagnosis spiritual distress. Rev Esc Enferm USP. 1994;28:125-36.

14. de Oliveira J, da Silva Brêtas J, Yamaguti L. A morte eo morrer segundo representações de estudantes de enfermagem. Rev Esc Enferm USP. 2007;41:386-94.

15. de Brito Pedrão R, Beresin R. O enfermeiro frente à questão da espiritualidade. Rev Einstein. 2010;8:86-91.

16. Anandarajah G, Hight E. Spirituality and medical practice: using the HOPE questions as a practical tool for spiritual assessment. Am Fam Phys. 2001;63:81-9.

17. Lucchetti G, Lucchetti AG, Badan-Neto AM, , Peres PT, Peres MF, Moreira-Almeida A, et al. Religiousness affects mental health, pain and quality of life in older people in an outpatient rehabilitation setting. J Rehabil Med 2011;43:316-22.

18. Rodrigues RM. Enfermagem compreendida como vocação e sua relação com as atitudes dos enfermeiros frente às condições de trabalho. Rev. Latino-Am. Enfermagem. 2001;9:76-82.

19. Mariotti L, Lucchetti G, Dantas M, Banin V, Fumelli F, Padula N. Spirituality and Medicine: views and opinions of teachers in a Brazilian Medical School. Med Teacher. 2011;33:339-40. 
20. Benko M, Silva M. Pensando a espiritualidade no ensino de graduação. Rev. Latino-Am. Enfermagem. 1996;4:71-85.

21. Gibertoni J. Assistência psicológica ao paciente para a cirurgia. Rev Bras Enferm. 1967;20:278-89.

22. Costa RdA, Shimizu HE. Atividades desenvolvidas pelos enfermeiros nas unidades de internação de um hospital-escola. Rev. Latino-Am. Enfermagem. 2005; 13:654-62. 